Rok Gregoríic

\title{
Sokratska prevara za resnico kot Kierkegaardov prehod med iracionalnostjo in racionalnostjo
}

\section{Socratic Deception in Service of the Truth as Kierkegaard's Pathway between Irrationality and Rationality}

Povzetek: Kierkegaardov pogled na človekove razumske zmožnosti v odnosu do vere predstavlja v interpretaciji njegovih del pomemben problem. Članek se osredotoča na vprašanje racionalnosti. Želi nasloviti dejstvo, da se Kierkegaardova misel na nekaterih mestih izraža iracionalno, medtem ko se na drugih kaže $v$ bolj racionalni luči. Članek dilemo poskuša videti v luči posebne metode, sokratske prevare, ki jo je Kierkegaard oblikoval po Sokratovem zgledu. Najprej prikažemo mesta, kjer se Kierkegaardova misel izraža kot iracionalna - v smeri bodisi fideizma bodisi relativizma. Članek nadalje ob zavedanju teh iracionalnih potez opiše, kako danski pisec z zgledovanjem po Sokratu predstavi posebno metodo prevare za resnico. Gre za hermenevtični ključ, ki nam omogoča Kierkegaardove prvotne očitke racionalnosti brati v luči širšega smisla. $V$ zadnjem delu se osredotočamo še na konkretne posledice, ki iz tega sokratskega prehoda izhajajo. Tako lahko še bolje osvetlimo, kakšne so značilnosti Kierkegaardove paradoksalne racionalnosti.

Ključne besede: Kierkegaard, Sokrat, psevdonim, prevara za resnico, racionalnost, razumeti, naravni razum.

Abstract: Kierkegaard's view on rational human abilities in relation to faith presents an important problem when researching his works. The article focuses on the question of rationality. It aims to explain the fact that in specific segments, Kierkegaard's thought seems irrational, while in others, it appears more rational. The article tries to see this dilemma in light of a particular method, the Socratic deception devised by Kierkegaard himself, whom Socrates inspired. First of all, segments in which Kierkegaard's thought appears irrational, either in the way of fideism or relativism, are shown. Being aware of these irrational characteristics, the article then describes how the Danish author presents a 
Socrates-inspired method of deception in service of the truth. This presents a hermeneutic key that offers his initial irrationalities to be read in a broader sense. The last part of the article aims to show specific consequences that emerge from this Socratic pathway. Thus, more characteristics are presented regarding Kierkegaard's paradoxical rationality.

Key words: Kierkegaard, Socrates, pseudonym, deception in service of the truth, rationality, to understand, natural reason.

Kot vsak filozof, ki se je kdaj ukvarjal z vprašanjem vere, se tudi Søren Kierkegaard ni mogel izogniti dilemi o pravem razmerju med vero in razumom. Vprašanje, kakšen odnos je do te problematike danski pisec vzpostavil, ostaja odprto za različne interpretacije - gotovo pa je, da ta tematika zavzema v njegovem pisanju pomembno mesto. Na tem mestu predstavljamo razmeroma izvirno interpretacijo, ki za Kierkegaarda v odnosu do vere priznava, da je pisec z mnogimi iracionalnimi potezami, a hkrati vse te poteze po Sokratovem zgledu zmožen povezati v smiselno skladnost. Da bi o tej njegovi metodi izvedeli več, moramo najprej upoštevati tisti del vsebine Kierkegaardovega pisanja, ki govori v smeri iracionalnosti. Zato je treba na začetku povzeti pomembnejše poteze, v katerih se danski pisec kaže kot nasprotnik razuma - kot zagovornik fideizma, individualizma in morda celo relativizma.

Pri ugotavljanju Kierkegaardovega odnosa do razuma moramo vsaj nekaj pozornosti nameniti avtorjevi osebni plati. Ta je namreč pomembno vplivala na njegova stališča in na način, kako je Kierkegaard razumel vero v svoji notranjosti ter kako jo je razlagal navzven, tudi v svojih delih. Dobro je vedeti, katere so bile tiste najpomembnejše poteze, ki so zaznamovale njegovo notranje dojemanje. Na prvem mestu je bil to lik njegovega očeta, ki mu je globoko v notranjost vcepil krivdo zaradi lastne velike zavrnitve Boga. Velik vpliv na Kierkegaardovo pisanje je imelo tudi dogajanje okoli njegovega ljubezenskega razmerja in zaročne zveze z Regino Olsen. Globoko ga je zaznamoval spor z dansko protestantsko skupnostjo, ki je v Kierkegaardovih očeh predstavljala primer poplitvenega množičnega krščanstva (Stres, 1998, 212). Ob teh treh poudarkih je njegovo notranje dojemanje bistvenih tematik, kot so Bog, vera, svet, družba in etika dobilo zelo specifičen značaj, ki se pogosto kaže $\checkmark$ paradoksalnosti in ekstremnosti. Pomemben izraz Kierkegaardove radikalnosti je tudi njegov odkrit boj proti Heglovi filozofski dediščini in nasprotovanje nemškemu idealizmu (Štrajn 2014, 103). Tu se pojavlja vprašanje, v kolikšni meri je Kierkegaardov napad na ustaljeno misel njegovega časa res odraz splošne zavrnitve racionalnosti? Ali je Kierkegaard s svojimi prispevkom res odločno usmerjen v napad na razum ali bi pri njem lahko našli tudi temelje za drugačno interpretacijo njegovih del - interpretacijo, ki navsezadnje, čeprav v paradoksalnem smislu, le išče racionalno skladnost? Namen našega prispevka je prikazati osnovne značilnosti Kierkegaardove obravnave razuma in razumevanja - tu je značilen poseben način branja, ki prvotne iracionalne poteze vključuje v racionalno skladnost. Prispevek poskuša na izviren način izvesti analizo hermenevtičnega ključa, kot ga v svojem pisanju predstavlja Kierkegaard sam. Ta princip je tudi za nas ključnega pomena, saj nam omogoča, da na prvotne očitke Kierkegaardovi iracionalnosti gledamo v drugačni luči. 


\section{Iracionalnost, fideizem in relativizem}

Pri mnogih bralcih Kierkegaardova dela puščajo vtis, kot da jih je napisal nekdo z radikalno iracionalnim stališčem do človekovega ravnanja in verovanja. Na prvem mestu lahko k temu prispeva Kierkegaardovo razmišljanje o veri. Zanjo pogosto pravi, da gre za skok, zaradi česar je navadno označen za fideista (Rae 2010, 55). Vera se mu kaže kot radikalna vsebina, za katero velja skrajna različnost od človeškega (Kierkegaard 1987, 49). Vera torej v duhu Luthrovega razmišljanja človeka nikakor ne preoblikuje od znotraj, temveč mu odrešenje prinese popolnoma od zunaj (Stres 1998, 216). Zaključek, ki lahko izhaja iz takšnih vtisov je, da Kierkegaardova vera pomeni neko arbitrarno odločitev volje in da človekove razumske sposobnosti nanjo ne morejo vplivati pozitivno (Coplestone 1963, 346).

Sposobnosti človekovega razuma se morajo po Kierkegaardovem mnenju varovati težnje po umni sintezi. Heglova misel se od Kierkegaardove najizraziteje razlikuje ravno v tej točki - slednji svojo dialektiko (341) utemeljuje na zavedanju, da znotraj uma do sprave med bistvenimi nasprotji v življenju ne more priti, Hegel pa umu pripisuje zmožnost, da do sprave privede vsa nasprotja, na katera naleti, in si na tak način vse podredi v nekakšno občo umnost. Pri Kierkegaardu je denimo močno naglašena razlika med notranjostjo in zunanjostjo, med Bogom in človekom (Kierkegaard 2005, 94). Od tod njegovo vero prežema močna individualistična konotacija - Kierkegaard namreč vero označuje kot novo notranjost, do katere človek pride $s$ tako imenovanim subjektivnim obratom. Vztrajanje v veri je tako neobhodno povezano s subjektivnim mišljenjem, ki pomeni naravnanost na lastno postajanje (Kierkegaard 1992, 73), naravnanost na zavedanje lastne eksistence. Ko bralec pri Kierkegaardu naleti na takšne misli, si zlahka ustvari vtis, da gre za misleca, ki vero razume na izrazito fideističen, individualističen ali celo relativističen način. Vtis o njegovi iracionalnosti pa se na tem mestu ne konča. Nekateri interpreti, kot sta Conant in Diamond, pri Kierkegaardu prepoznavajo še močnejšo misel, ki želi nad vse povzdigniti idejo (če jo sploh smemo označiti za idejo) nesmisla (Lippit in Hutto 1998, 269). Prav tako niso redke interpretacije v smislu, da Kierkegaard vse obravnavane tematike izpostavlja nevarnosti absolutne negacije (Novak 2014, 305). $\checkmark$ podporo iracionalnemu značaju njegovega pisanja govori tudi dejstvo, da se pogosto zelo izrazito izreka proti vsakršnemu dokazovanju Boga (Kierkegaard 1987, 45), proti etičnemu stadiju, ki pomeni življenje znotraj okvirov občega $(2005,77)$, in da ponekod s pridom uporablja izraze z močno iracionalno konotacijo (1987, 127). Kierkegaard s svojimi psevdonimnimi deli ustvarja občutek, kot da je vera zanj vse, kar radikalno nasprotuje razumu. Izjave, v katerih zavrača zgodovino, razum, politiko in predvsem sistem (Stres 1998, 218), dajejo močan občutek, da se njegova misel o veri v vseh pogledih kaže kot fideizem. Kot bomo videli v nadaljevanju, pa psevdonimno pisanje ni edino, kar je Kierkegaard pri podajanju svoje misli uporabil. Upoštevanja vreden je tudi prispevek, ki ga je podpisal z lastnim imenom in priimkom - njegova primarna avtorska dela. Tu so Kierkegaardove iracionalne izjave postavljene v drugačno luč. Tu je, kot bomo videli, avtor sam razložil način, kako vse njegovo še tako protirazumsko pisanje služi širšemu smislu. 


\section{Zgled Sokrata}

Kierkegaard je v svojem intelektualnem ustvarjanju pokazal veliko naklonjenost do grške filozofske tradicije. Že v tej potezi lahko spoznamo, da danski pisec ne kaže več tako radikalne drže, saj podobno kot racionalno usmerjeni filozofi osrednjemu obdobju zgodovine filozofije priznava zelo visoko mesto. Grški dediščini, čeprav predkrščanski, je po njegovem treba vsaj v nečem prikimati (Kierkegaard 1987, 149). Osrednja točka, kjer grško dediščino Kierkegaard prepoznava za pozitivno, je dejstvo, da lahko starogrške filozofe smiselno uporabi v svojem intelektualnem spopadu s heglovstvom (149). Posamezne predstavnike grške misli, kot so Heraklit in njemu nasprotni eleati, je $v$ njihovih konkretnih dilemah prepoznal kot navdih $v$ svojem boju proti nemškemu idealizmu (Štrajn 2014, 103). Med mnogimi velikimi osebnostmi pa mu je daleč največ pomenil plemeniti modrijan Sokrat (Kierkegaard 2014, 236). Lahko bi rekli, da si ga je vzel za vzor svojemu filozofskemu razglabljanju - predstavljal mu je poglavitni navdih pri formiranju lastnega filozofskega jezika. Lik starogrškega Sokrata moramo zato upoštevati, tudi ko se želimo dotakniti vprašanja Kierkegaardove racionalnosti. Atenski modrec namreč predstavlja temeljni vzor za Kierkegaardov odnos do razuma - in prav tako za njegov način posredovanja vere. $\checkmark$ razumevanju sokratskega značaja Kierkegaardove misli lahko spoznamo globljo perspektivo Kierkegaardove misli, tudi tiste, ki se izraža iracionalno.

Ob proučevanju tega lika v Kierkegaardovih delih najprej opazimo zanimivo navezavo na Sokratov odnos do modrosti: »Občudoval sem njegovo modrost, občudoval sem ga, da je $v$ svoji modrosti postal preprost in bil sposoben premagati spretneže« (236-237). Navdihuje ga Sokratova splošno znana dvojna poteza: po eni strani je moder, da premaga spretneže, po drugi strani pa z modrostjo postane preprost, celo neveden (236). Prav ta dvojni vidik Sokratove (ne)vednosti je Kierkegaard prepoznal kot izjemno učinkovit za podajanje resnice, za poučevanje in pisanje. Ne samo, da si je Atenec s takšnim načinom pridobil vrlino samoodpovedi, ampak si je s tem ustvaril lažji dostop do učenca $(2012,351)$. Biti učitelj v sokratskem razumevanju pomeni biti učencu povod za njegovo razumevanje, prav tako pa je tudi učenec lahko povod za učiteljevo boljše razumevanje $(1987,28)$. V središču je torej vrlina samoodpovedi, ki jo je Kierkegaard pri Sokratu visoko cenil. Njena pomembnost je v tem, da je danskemu piscu omogočila vključiti Sokratove smernice $v$ lastno krščansko razmišljanje. Kierkegaard je namreč svojo versko formacijo pridobil v okolju, prežetem z izrazito ortodoksnimi protestantskimi temelji, po katerih pretirano vključevanje posvetne, še manj pa predkrščanske filozofije v religijo ni bilo dobrodošlo. Zato nikakor ni samoumevno, da je kljub tej strogi poziciji, s katero doktrinalno ni imel težav (Rae 2010, 13-14), v svoje misli tako intenzivno vključeval tudi misel atenskega modreca. Slednje mu je omogočil ravno Sokratov poudarek na samoumiku (Kierkegaard 2012, 351), saj le zaradi ideje samoodpovedi ni prišlo do nasprotja s krščanskim naukom - kjer je samoodpoved, tam je tudi mesto za krščanstvo. Biti povod učencu in potem še prikriti svojo pomoč (351), to je Kierkegaard prepoznal ne samo kot nekaj za krščansko oznanilo neškodljivega, ampak tudi kot nekaj precej koristnega za uvajanje v pravi odnos 
do Boga. Sokrata zato razmeroma utemeljeno označuje za najbližjega krščanstvu $(2014,236)$. Sicer drži, da o vseh podrobnostih pogleda na človeka in resnico Kierkegaard Sokratovega mnenja ni delil (Rae 2010, 42) - njuna podobnost pride najbolj do izraza v tem, da se je želel zgledovati po Sokratovem vedênju, po njegovem načinu življenja, učenja in izražanja.

\section{Poteze sokratske prevare}

Sokratski pristop v mišljenju in izražanju misli je Kierkegaarda zaznamoval v mnogih potezah. Eden zanimivejših načinov, s katerim je svoje pisanje uvedel v sokratsko metodo, je uporaba psevdonimov - velik del Kierkegaardovega korpusa namreč obsegajo dela, ki so podpisana z izmišljenimi imeni. Tako je nastalo več kot deset psevdonimov, s katerimi je podpisan tudi pod svojimi najslavnejšimi deli. Ob spraševanju, zakaj se je Kierkegaard odločil za takšen način pisanja, je najprej treba upoštevati predvsem njegove lastne razlage, ki jih morda lahko apliciramo tudi na konkretna dela. Knjiga, ki predstavlja nekakšen prehod med psevdonimnimi in avtorsko podpisanimi deli, Zaključni neznanstveni pripis k Filozofskim drobtinicam, tako prinaša nekaj pomembnih poudarkov. V njej namreč Kierkegaard pri nekaterih svojih psevdonimih razlaga, kako izmišljene osebnosti deloma prinašajo vsebino njegovih stališč, delno pa se od njih tudi razlikujejo (Kierkegaard 1992, 24). Poudariti je treba, da takšna dela in razmišljanja, ki jih vsebujejo, njihov dejanski pisec do neke mere preklicuje. V kolikšni meri ta preklic velja, sicer ostaja vprašanje, a središče pozornosti želi Kierkegaard prenesti na pričevanjsko vlogo - kot pričevanje o bivanjskih odnosih posamičnika (Ule 2014, 186-190). Poleg tega je med interpreti Kierkegaardovih del razširjeno mnenje, da vsebina psevdonimnega pisanja služi širšemu pomenu in smislu. Čeprav dejstvo njihovega obstoja znotraj Kierkegaardovega korpusa izraža nekakšno zmedo, marsikateri razlagalec trdi, da takšen vtis ustvarjajo namenoma - da torej danski pisec z njimi »zavestno pristane na to, da bi izpadel nerazumljivo« (McCombs 2013, 20). Tudi vidik Kierkegaardove dialektičnosti je pri njegovih psevdonimih precej jasno izražen. Z uporabo psevdonima namreč Kierkegaard poglobljenega bralca vabi v novo razmerje. Psevdonim ne pove veliko v smislu ustaljenih informacij - več pove s tem, da bralca s svojo dialektičnostjo privabi v iskanje razlage (Vodičar 2014, 365). Vsekakor je Kierkegaard s psevdonimom želel posredovati neko svojo vsebino, toda s specifično konotacijo, značilno za vsak izmišljeni lik - in s prav posebnim ciljem pri bralcih (Mulder 2010, 6).

Z vidika mojega pisateljstva - osrednje delo, v katerem Kierkegaard razlaga svoj način pisanja - psevdonimno pisanje povezuje s temo, ki je ključna za ugotavljanje njegovega vrednotenja razuma:

„Vendar je z vidika celote pisateljstva estetično pisanje prevara, in v tem je globlji pomen psevdonimnega. Toda prevara, ali ni to nekaj nadvse odvratnega? Na to bi odgovoril: ne pustite se zavesti z besedo prevara. Ne- 
koga lahko prevaramo zaradi resnice in - spomnimo se na starega Sokrata - človeka lahko prevaramo v tem, kar je resnica. Ja, prav res, edinole na tak način, da ga preslepimo, je mogoče človeka, ki je v utvari, privesti $\mathrm{k}$ resnici.« (Kierkegaard 2012, 54)

Tema prevare, ki je za Kierkegaarda osrednja značilnost Sokratove govorice, dodobra zaznamuje njegovo pisateljsko delo, v katerem želi zamajati množični tok poplitvenega krščanstva (109). Prevara pomeni preprosto to, da sporočila ne začnemo neposredno s tistim, kar želimo od poslušalca doseči (55). Razlog za to je dejstvo, da poslušalec za resnico ni dovzeten in namesto nje vztraja v estetični zablodi. Iz tega izhaja Sokratovo didaktično načelo, da je takšnega človeka treba na neki način preslepiti (54). Ker je v Kierkegaardovih očeh večina ljudi v resnici živela $v$ stadiju estetičnega, ob tem pa je sama menila, da je popolnoma krščanska (55), je v Sokratovi prevari videl najboljšo možnost za oznanilo resnice. Začel je pisati v estetičnih opredelitvah (55), sporočila resnice pa se je v neposrednem smislu vzdržal (109).

Ena pomembnejših potez prevare je torej izogib neposrednosti sporočila. Tak način izražanja bi v določenem smislu lahko povezali s pojmom metaforične govorice. Ta je namreč na podoben način - z izogibanjem jasnosti in enopomenskosti - različnim filozofom služila kot sredstvo za prikaz občih jasnosti v luči nejasnosti in iluzije (Vodičar 2017, 574). Po besedah Kierkegaarda je težnja po neposrednosti v človekovem odnosu do Boga »preprosto rečeno poganstvo«, da torej na tak način Bogu želi vsiljevati lastne podobe in želje (Kierkegaard 1992, 243). S tem se odpira možnost prevare kot tiste, ki s svojo posrednostjo - ta vključuje vsaj minimalno zavedanje presežnosti - lahko precej učinkovito pokaže na pravo resnico $(2012,54)$. Kierkegaardova psevdonimna dela so po njegovih lastnih besedah namenjena prav temu, da intenzivneje uporabljajo prevaro v odnosu do estetično zavedene javnosti. Čeprav so namenjena predvsem ljudem brez pravega zavedanja lastne eksistence in Božje izmuzljivosti (1992, 243-244), pa po drugi strani niso prav nič škodljiva za tiste, ki vero že razumejo pravilno in jo v življenju tudi uresničujejo - tem, ki vse ljubijo in verujejo, nobena prevara ne more do živega, saj v tem, da verujejo in ljubijo, ne morejo biti prevarani $(2012,306)$. Sicer pa bralcem, ki se v svoji notranjosti že iskreno trudijo vstopiti v religiozni stadij in tako v glavnini svoje biti zavreči estetično, Kierkegaard bolj izrazito namenja dela svojega primarnega avtorstva, torej dela podpisana z dejanskim imenom in priimkom. Dva reda njegovega pisanja - primarno in psevdonimno - sta torej namenjena smiselnemu prepletu med sokratsko prevaro za resnico in bolj jasnim, a še vedno posrednim oznanilom resnice, ki pa je vselej resnica krščanstva. Za celoto Kierkegaardovega pisateljstva, bodisi primarnega bodisi psevdonimnega, torej vseskozi stoji precej presenetljiva smiselnost, predvsem pa vztrajen razlog religioznega. ${ }^{1}$

Postavlja se vprašanje, ali je imel Kierkegaard načrt takega dvojnega pisateljstva v religioznem pomenu, kot ga sam razlaga $v$ delu $Z$ vidika mojega pisateljstva, zares v mislih že od začetka svojega pisanja. Nekateri interpreti, med njimi Caputo, namreč sumijo, da je religiozno razlago svojih psevdonimnih del ustvaril šele v poznih letih (Caputo 2008, 71). 
Pomembna poteza, ki je značilna za Kierkegaardov sokratski način izražanja, je tudi izrazit odpor sveta, ki ga takšen sokratski učitelj pri svojem delovanju vselej doživlja. Ker »svet ni bil nikdar dorasel temu, da bi večina ljudi glasovala za resnico ali imela o njej pravilno predstavo«, je potemtakem jasno, da do pravilnega posredovanja resnice, ki ga prinaša sokratski učitelj, občuti močno nelagodje $(2012,459)$. Po Kierkegaardovih besedah se ob stiku med svetom in človekom resnice ustvarijo pogoji, da lahko pride do »pravcatega trčenja « (453), tako pa tudi do priložnosti, da človek, ki izhaja iz množice, izstopi iz estetičnega ugodja in se obrne navznoter (452) - tudi mimo zunanjih predmetov (453). Svet, ki pomeni množično predajanje družbe estetičnemu, sokratske nesebičnosti ne zmore priznati za pozitivno (351). V krščanskem razumevanju se lahko sokratska prevara uporabi za klic k zavedanju Božje presežnosti, da se na tak način zavaruje pred neresnico $(1992,244)$. Misel množice, zaznamovana z nenasitno težnjo po neposrednosti in obvladovanju vsega, pa takšnega samoponižanja ne sprejema. Pristnemu oznanjevalcu resnice namesto priznanja namenja trpko zavrnitev, zato velja Kierkegaardovo opozorilo, da vsakega avtentičnega učitelja resnice čaka huda preizkušnja: skušali ga bodo spodkopati, ga vpeljati nazaj v množico ter uničiti ves njegov oznanjevalni trud. $(2012,459)$ Na kocki je pravzaprav pravilno razumevanje resnice - tega pa množica ni sposobna ponuditi. Kierkegaard gre v svojem razmišljanju celo tako daleč, da lahko prav nasprotovanje množice uporabi za argument pravega razumevanja - dokaz za to, da je oznanjevalec zvest resnici, je to, da je preganjan (79). Pravilno razumevanje se lahko zgodi le v človeku samem, dogaja se $v$ notranjosti in v njegovi notranjosti ga tudi določa. Pravo razumevanje sega v globino in je neobhodno povezano s smislom življenja (Pavliková in Žalec 2019, 1023). Nemogoče je nekaj pravilno razumeti, ne da bi nas tisto, kar razumemo, določalo kot človeka. »/meti razumevanje za nekaj pomeni že neke vrste sporazum, dogovor med osebo, ki je razumela, in med stvarjo, ki je razumljena« (Kierkegaard 2012, 363). Zavest pravega razumevanja je torej tisto, k čemur Kierkegaard želi spodbuditi svoje bralce.

Največja laž, ki jo človeku želi prodati svet, je v tem, da je razumljeno lahko ločeno od osebe, ki razume. Bitka za resnico, v kateri Sokrat in Kierkegaard uporabljata tudi prevaro, odpira zavest poslušalca in bralca za drugačno dojemanje táko, ki ne pristaja na udobno ločevanje med tistim, ki razume, in stvarjo, ki je razumljena. $V$ nasprotju z lažnim ponuja pravo razumevanje kot tisto, ki človeka celostno določa, čeprav mora človek v ta namen žrtvovati svojo lahkotno ustaljenost. Tu se kaže še ena pomembna lastnost sokratske prevare, torej razločevanje med pravim in lažnim razumevanjem, med razumeti in »razumeti « $(1987,123)$. V Kierkegaardovem času je v filozofski misli prednjačila paradigma o ločenosti med predmetom (objektom), ki je proučevan, in osebo, ki ga proučuje. Ta pojav, navadno imenovan objektivizacija, je Kierkegaard pogosto problematiziral - predvsem ko je šlo za vprašanje eksistence. Razumeti sebe v tem, kar razumemo $(1998,172)$, za učenjake njegovega časa ni bilo tema, o kateri bi bilo vredno razmišljati. Kierkegaard je s svojo prevaro klical k nasprotnemu - k notranjosti, k obrnjenosti navznoter, k zavesti o sebi in o lastnem delovanju (2012, 452). Želel je povedati, da 
življenje človeka ne poteka samo po znanstvenih načelih, po načelih objektivizacije in distance do samega sebe. Lahko bi rekli, da mora biti življenje ne zgolj proučevano, ampak res v polnosti živeto (Klun 2014, 387). Kierkegaardovo svarilo pred tem, da bi znanstvena obravnava prekomerno posegla $v$ odnos do lastne eksistence in ga tako poplitvila, izvira iz nevarnosti, da bi bivanje izgubilo lastno avtentičnost (Evans 1987, 179). Skrbi ga, da je človeška družba zaradi osredotočenosti na trenutek izpred oči izgubila večnost: »Kar koli spoznavamo, spoznamo na lahkoten način, kot pamflet ali uglajeno laž, kjer ena neresnica podpira drugo" (Kierkegaard 2012, 461). Realnost tega nepravega spoznanja je torej laž, še več - je pravi preplet laži, kjer te druga drugo podpirajo. Kierkegaard pa po drugi strani skupaj s Sokratom trdi, da je nemogoče nekaj prav razumeti, če nas to razumevanje ne nagne tudi k pravemu ravnanju $(1987,123)$. Od tod se potrjuje tudi Sokratova opredelitev greha kot nevednosti (119).

Na poti k razumevanju preko sokratske prevare se kot pomembni kažeta tudi ironija in humor. Ironija kot sredstvo je za človeka priložnost, da sam do sebe zavzame nekakšno obliko distance (Golomb 1991, 72). To je - drugače kot znanstveni pristop, ki v odnosu do eksistence ni primeren - pozitivni način vzpostavitve distance, $v$ katerem se človek poniža $(2012,42)$ in v katerem je zmožen preveriti svoja dejanja ter biti do sebe iskren $(1991,72)$. Podobno kot je Sokrat Atencem, zaslepljenim od sofizma, z ironijo želel pomagati k resnici, želi tudi Kierkegaard bralce, ujete v estetično zmoto, s humorjem predramiti za religiozno resnico. Sokratova ironija se po Kierkegaardovih besedah spopada s protislovjem med obema vrstama razumevanja (Kierkegaard 1987, 121). Iz napisanega bi lahko sklepali, da po Sokratovem mnenju na neki način že s tem, ko se tega protislovja začnemo zavedati, vstopamo v pravo razumevanje. Zahvaljujoč krščanskemu nauku se Kierkegaardovo stališče na tem mestu od Sokratovega malenkostno razlikuje - danskemu piscu je za razliko od atenskega misleca že dostopen zaklad vere v Kristusa. Vloga ironičnega je zato $v$ njegovih delih prilagojena oznanilu krščanske resnice, ki pa je človek ne more osvojiti zgolj s sokratskim zavedanjem, ampak z vero $v$ odrešenika Jezusa, ${ }^{2}$ ki mu omogoča novo življenje. Zaradi tega Kierkegaard svoje oznanjevanje večkrat označuje $z$ besedo humor, Sokratovo učenje pa z besedo ironija. Izraza sta si podobna v tem, da se $v$ odnosu do sveta oba izražata polemično $(2012,79)$. Poleg tega se oba jasno izražata zgolj kot sredstvi in ne kot cilja neke filozofske misli (Golomb 1991, 72). Humor se od ironije razlikuje zgolj v tem, da z izražanjem protislovja bivanja hkrati izraža tudi religiozno resnico eksistence (Evans $1987,179)$. Medtem ko beseda ironija v Kierkegaardovi govorici označuje bolj prehod med estetičnim in etičnim, ima beseda humor že značaj prehoda k religioznemu - oznanjevalec ga uporablja izključno z namenom, da bi v krščanskem smislu oznanjal in vabil k veri in k novemu življenju $(1998,269)$.

Med najpomembnejše poteze Kierkegaardovega sokratskega poučevanja je treba prišteti tudi poudarek na pozornosti do učečega se. Zdi se razvidno, da vsak

Tu se kaže skoraj edina močnejša razlika med Sokratovim in Kierkegaardovim mišljenjem - vprašanje dostopa do resnice (Rae 2010, 42). 
človek, ne zgolj učitelj, že stopa po neki poti k popolnosti. Zato se tudi Kierkegaardu zdi edino smiselno, da prva učiteljeva dolžnost ob interakciji z učencem ni to, da ga začne neposredno uvajati v večje razumevanje. Čeprav seveda učitelj ve več kot učeči se, mora najprej sam spoznati, na kateri točki učeči se je - šele ko se pred njim tako poniža, mu postane sposoben zares pomagati $(2012,42)$. Učitelj pravega razumevanja je to vedno pripravljen storiti. Ko denimo sreča nekoga na ulici ali - v Kierkegaardovem primeru - ko nagovarja svojega bralca, se mora najprej spustiti na njegov nivo, da lahko potem njega povabi višje - na mesto, kjer je on sam (44). Učitelji, ki se po tem načelu ne ravnajo niti v najmanjši meri, svojim učencem ne morejo nuditi pomoči. Boljše razumevanje, ki ga glede na učence posedujejo, se na druge ne more prenesti zaradi drže zaprtosti - in jim tako pri učenju nič ne pripomore (42). Učeča ponižnost je torej tisto metodološko izhodišče, iz katerega sokratski učitelj izhaja vedno znova. Sokrat je to uresničeval v pogovorih na atenskih ulicah in v svojem krogu učencev, Kierkegaard pa je to želel posnemati še pri pisanju knjig. Uporablja praktično vse mogoče oblike estetskega življenja, jih pretvarja v psevdonime - izmisli si njihove osebne situacije in zgodbe, potem pa se vanje vživi ter napiše knjigo, kot bi jo ti napisali sami. Vse to je storil v sklopu majevtične prevare - in z izključnim namenom posredovati oznanilo Jezusa Kristusa. Uporabil je Sokratovo načelo, da »biti učitelj v resnici pomeni biti učeči (44).

\section{Konkretne implikacije prehoda k pravemu razumevanju}

Vprašanje racionalnosti je torej pri Kierkegaardu zaznamovano s prehodom od lažnega k pravemu razumevanju s pomočjo sokratske prevare. Ob upoštevanju te ideje lahko ob proučevanju Kierkegaardovih del najdemo mesta, pri katerih se zdi, da je ta prehod že upoštevan. $V$ njegovih delih tako $v$ odnosu do racionalnosti prepoznamo nekakšno dvojnost: v psevdonimnih delih do razuma odklonilen odnos, $v$ avtorsko podpisanih pa afirmativen. Razlog za to je, da človek na tem svetu resnico vidi zgolj zamegljeno, „temačno skozi steklo, bi lahko rekli« (Rae 2010, 54). Tudi dvoumnost terminologije, ki na eni strani poudarja vero kot paradoks (Kierkegaard 1992, 205), na drugi pa kot izpolnjenost zavesti $(2017,92)$ in razumevanja $(1987,121)$, je Kierkegaard razložil z izjavo, da večna resnica ni paradoks v odnosu do sebe, se pa kot paradoks kaže v odnosu do omejenega človeka (1992, 205). Prehod od perspektive paradoksa do perspektive resnice, kjer se ta ne kaže več kot paradoks, ${ }^{3}$ je možen prav po poti sokratsko obarvanega vstopa v vero. Poleg terminologije racionalnosti je kot rezultat sokratske prevare za resnico mogoče prepoznati tudi poudarek na konkretnosti. Ta izhaja iz poudarka glede povezanosti med pravim razumevanjem in življenjem posamičnika. Kierkegaard tu naglašuje nevarnost, ki jo pomeni znanstveno proučevanje v odnosu do eksistence:

S poudarjanjem paradoksa Kierkegaard želi pokazati, da transcendentne resnice Boga ne gre jemati zlahka ali je enostavno povezovati z zemeljskimi kategorijami (Petkovšek 2015, 238). 
tvori sicer pomembne objektivne miselne strukture, a te posamezniku nič ne koristijo, če jih ne usvoji tudi njegov subjekt in jih naposled privede v konkretnost (Grlić 1973, 229). Ključen problem človeka je prehod od razumevanja do ravnanja - tu se začenja krščanstvo, ki s svojo paradoksalnostjo premosti razdaljo med enim in drugim (Kierkegaard 1987, 123).

Konkretna posledica sokratskega prehoda je tudi Kierkegaardovo priznavanje pozitivne vloge naravnih pogojev za spoznanje Boga. Tu lahko do neke mere govorimo tudi o priznanju naravnega razuma, ki človeku do določene mere lahko pomaga do vere. Gre za to, da vsak posameznik v sebi že zaradi naravne ustvarjenosti poseduje neko spoznanje o Bogu, s tem spoznanjem pa potem bodisi v vero vstopi bodisi ga v grehu zavrne $(2012,106)$. Ideja fundamentalnega spoznanja o Bogu je pri Kierkegaardu sicer nejasna, očitno pa je, da jo avtor na neki način priznava (Mulder 2010, 28). Ker torej po njegovem mnenju obstaja neko splošno naravno razumevanje, dano vsem ljudem, je potemtakem logična tudi izpeljava o vrednotenju teološkega govora. Slehernemu izmed nas so po naravnem razumu dana merila, da se s pomočjo njih izražamo o vsem okoli nas. Tako se, če le želimo kaj povedati oziroma če hočemo oznanjati svojo vero, ljudje moremo in moramo poslužiti teh meril tudi v odnosu do Boga (Kierkegaard 2014, 284). Danosti, ki so predhodno dane vsem, so po uporabi sokratske prevare, ki je preprečila njihovo zlorabo, in so prikazane kot del Božjega načrta. In čeprav Kierkegaard kot bistveno, kar vse nas povezuje, izpostavlja bistveno drugačnost, je ta vsem skupna - in v perspektivi krščanske celote poenotena $(2012,118)$. Ni pa poenotena na način heglovske sprave (Coplestone 1963, 341) - Kierkegaardova misel pravi zgolj to, da posamičnik v stremljenju k eksistencialni resnici postaja zvest svoji celovitosti (Collins 2014, 257), ni pa mu tega stremljenja treba nujno uresničiti - posameznik ima pri Kierkegaardu v nasprotju s Heglovo mislijo tudi možnost, da eksistencialno resnico dokončno zavrne. Spoznali smo, da je v tej celostni perspektivi tudi človeški razum vsekakor mogoče videti v pozitivni luči (McCombs 2013, 11). Kierkegaardovo priznavanje naravnih zmožnosti se tu ne konča. Pozitivno namreč vrednoti tudi koncept naravne ljubezni, ki se je sicer resda dolžna umakniti čisti ljubezni, ostane pa še vedno pomembna na sekundarni ravni (Mulder 2013, 76). Ta ljubezen se mora tako v zakonskem (Kierkegaard 2003, 404) kot v prijateljskem (551) odnosu presojati tudi z naravno močjo razuma. Posameznik ima na voljo dejavnike, ki mu pomagajo presojati, ali je neka ljubezen, ki jo izkuša, prava ali neprava (Žalec 2016, 288). Poleg tega na tej točki kot smiseln prepoznava tudi etični stadij, ki ga pri vstopu v vero označuje za možni sprožilni dejavnik (Teodorescu 2016, 115). ${ }^{4}$ Etika namreč dokončno utemeljitev dobi samo z vero, vsaka druga utemeljitev tako ali drugače privede do neodločenosti (Jamnik 2018, 344). Potemtakem pri Kierkegaardu biti veren postane smiselna razrešitev vprašanja etičnosti (Žalec 2019, 635).

4 Teodorescu poleg tega kot sprožilni dejavnik za Kierkegaardovo vero prepoznava pragmatični postulat na podlagi eksistencialnega obupa. Posameznik pragmatično predpostavlja, da obstaja osebni Bog, ki ga lahko reši iz osebnega obupa (Teodorescu 2016, 113). 


\section{Sklep}

Kierkegaard pri vprašanju racionalnosti izstopa $v$ tem, da močno poudarja razliko med pravim razumevanjem, ki ga povezuje tudi z religioznim podukom (Kierkegaard 2012, 94), in lažnim. Zametek slednjega danski pisec prepoznava v napačni zamisli ljubezni (2012, 212), ki želi ločevati med živetim in razumljenim. Za Kierkegaarda je ključnega pomena predvsem subjektivno védenje - védenje, povezano s človekovo eksistenco in zmožno notranje vplivati na subjekt (Teodorescu $2016,107)$. Subjektivno védenje, kot nam razlaga Kierkegaard, vključuje tudi sposobnosti, ki jih imamo ljudje kot naravne danosti. V subjektivnem védenju te naravne sposobnosti nikakor niso preklicane, so pa z vero obvarovane pred samoljubjem (Žalec 2017, 253). Poglavitna naloga človeka v življenju je, da uresničuje samega sebe v tem, da je najbolj on sam (Teodorescu 2016, 114) - da torej postane posamičnik. Tu je temelj Kierkegaardove paradoksalne misli, ki preko sokratskega prehoda iz iracionalnih izhodišč postane na neki način racionalna. Po Kierkegaardu je pravo razumevanje tisto, ki posamezniku pomaga pri njegovem projektu postati posamičnik. Pravo razumevanje posamičnika usmerja, da je vse bolj " prosojno zasidran v moči, ki ga je vzpostavila (Kierkegaard 1987, 156). Tu pa je, kot smo lahko spoznali, zelo v pomoč prav sokratska prevara za resnico.

\section{Reference}

Caputo, John D. 2008. How to Read Kierkegaard. New York: W. W. Norton \& Company.

Collins, James Daniel. 2014. The Mind of Kierkegaard. New Jersey: Princeton University Press.

Copleston, Frederick. 1963. A History of Philosophy. Zv. 7. New York: Paulist Press.

Evans, C. Stephen. 1987. Kierkegaard's View of Humor: Must Christians Always be Solemn? Faith and Philosophy: Journal of the Society of Christian Philosophers 4, št. 2:176-186. https:// doi.org/10.5840/faithphil19874220

Golomb, Jacob. 1992. Kierkegaard's Ironic Ladder to Authentic Faith. International Journal for Philosophy of Religion 32, št. 2: 65-81. https:// doi.org/10.1007/bf01315425

Grlić, Danko, ur. 1973. Filozofija. Beograd: Interpres.

Jamnik, Anton. 2018. Etični imperativ med transcendenco postmoderne in imanenco liberalizma. Bogoslovni vestnik 78, št. 2:334-347.

Kierkegaard, Søren. 1987. Bolezen za smrt: Krščanska psihološka razprava za spodbudo in prebujo in Trije spodbudni govori. Celje: Mohorjeva družba.

- - - 1987. Ponovitev; Filozofske drobtinice ali Drobec filozofije. Ljubljana: Slovenska matica.

- - . 1992. Concluding Unscientific Postscript to
Philosophical Fragments. Zv. 1. New Jersey: Princeton University Press.

- - . 1998. Pojem tesnobe: Preprosto psihološko nazorno razmišljanje $v$ smeri dogmatičnega problema izvirnega greha. Ljubljana: Slovenska matica.

- - . 2003. Ali-ali. Ljubljana: Študentska založba.

---. 2005. Strah in trepet. Ljubljana: KUD Apokalipsa.

- - - 2012. Dejanja ljubezni. Ljubljana: Družina.

- - - 2012. Z vidika mojega pisateljstva. Ljubljana: KUD Apokalipsa.

- - - 2014. Krščanski (na)govori. Celje: Celjska Mohorjeva družba.

- - - 2017. Johannes Climacus ali De omnibus dubitandum est. Ljubljana: KUD Apokalipsa.

Klun, Branko. 2014. Metodološke predpostavke Kierkegaardove antropologije. V: Repar 2014, 376-389.

Lippit, John, in Daniel D. Hutto. 1998. Making Sense of Nonsense: Kierkegaard and Wittgenstein. Proceedings of the Aristotelian Society, št. 98:263-286.

McCombs, Richard Phillip. 2013. Paradoxical Rationality of Søren Kierkegaard. Bloomington: Indiana University Press.

Mulder, Jack, Jr. 2010. Kierkegaard and the Catho- 
lic Tradition: Conflict and Dialogue. Bloomington: Indiana University Press.

Novak, Bogomir. 2014. Poskus razumevanja Kierkegaardovega eksistencialnega Boga. V: Repar 2014, 277-307.

Pavliková, Martina, in Bojan Žalec. 2019. Boj za človekov jaz in pristnost: Kierkegaardova kritika javnosti, uveljavljenega reda, medijev in lažnega krščanstva. Bogoslovni vestnik 79, št. 4:1015-1026.

Petkovšek, Robert. 2015. Demonično nasilje, laž in resnica. Bogoslovni vestnik 75, št. 2: 233251.

Rae, Murray. 2010. Kierkegaard and Theology. London: T\&T Clark International.

Repar, Primož, ur. 2014. Nova oikonomija odnosov: bližnjik in eksistencialni preobrat. Ljubljana: KUD Apokalipsa.

Stres, Anton. 1998. Zgodovina novoveške filozofije. Priročniki Teološke fakultete 15. Ljubljana: Družina.

Štrajn, Darko. 2014. O začetku Kierkegaardove filozofije. V: Repar 2014, 97-105.
Teodorescu, Valentin-Petru. 2016. Kierkegaard and the Knowledge of God. V: Titus Corlăţean in loan-Gheorghe Rotaru, ur. Proceedings of Harvard Square Symposium: The Future of Knowledge. Zv. 1, 105-127. Beltsville: Scientific Press.

Ule, Andrej. 2014. Zaletavanje v paradoks pri Wittgensteinu in Kierkegaardu. V: Repar 2014, 180-198.

Vodičar, Janez. 2014. Konflikt interpretacij - med vero vase in negotovostjo sveta. V: Repar 2014, 362-375.

- - - 2017. Živa metafora kot možna pot do transcendence. Bogoslovni vestnik 77, št 3/4:565576.

Žalec, Bojan. 2016. Kierkegaard, ljubezen kot dolžnost in žrtvovanje. Bogoslovni vestnik 76, št. 2:277-298.

- - - 2017. Kierkegaard in politično: vera kot premagovanje nasilja in vir demokracije. Bogoslovni vestnik 77, št. 2:247-259.

- - - 2019. Liberalna evgenika kot uničevalka temeljev morale: Habermasova kritika. Bogoslovni vestnik 79, št. 3:629-641. 